\title{
Andorra: Assessment of Financial Sector Supervision and Regulation
}

This Assessment of Financial Sector Supervision and Regulation in Andorra in the context of the offshore financial center assessment program contains technical advice and recommendations given by the staff team of the International Monetary Fund in response to a request for technical assistance by the authorities of Andorra. It is based on the information available at the time the report was completed on February 5, 2007. The views expressed in this document are those of the staff team and do not necessarily reflect the views of the government of Andorra or the Executive Board of the IMF.

The policy of publication of staff reports and other documents by the IMF allows for the deletion of market-sensitive information.

To assist the IMF in evaluating the publication policy, reader comments are invited and may be sent by e-mail to publicationpolicy@imf.org.

Copies of this report are available to the public from International Monetary Fund $\bullet$ Publication Services

700 19th Street, N.W. • Washington, D.C. 20431

Telephone: (202) 6237430 • Telefax: (202) 6237201

E-mail: publications@imf.org • Internet: http://www.imf.org

Price: $\$ 18.00$ a copy

\section{International Monetary Fund Washington, D.C.}



INTERNATIONAL MONETARY FUND

ANDORRA

ASSESSMENT OF FinANCIAL SECTOR SUPERVISION AND REgULATION

Prepared by Monetary and Capital Markets Department

Approved by Jonathan Fiechter

February 5, 2007

This report is based primarily on work undertaken during a visit to Andorra in the period September 18 to 28, 2006. The assessment team comprised Mmes. Socorro Heysen (Mission Chief) and Alicia Novoa (both MCM); Mr. Ruben Mendiolaza (Superintendency of Banks and Insurance Companies of Peru); and Messrs. Piotr Andrzejewski, and Walter Zunic (both consultants). The main findings of the assessment are:

- $\quad$ Bank supervision is broadly sound and has improved since the 2002 assessment.

- INAF's new charter strengthened its independence and remedial powers. But these could be further strengthened by empowering it to impose all types of sanctions.

- $\quad$ Developing INAF's on-site supervisory capacity and clarifying its requests to external auditors will be key for the bank and nonbank financial sectors.

- $\quad$ The increasing importance of collective investment schemes (CIS) and life insurance business raises the need to recast their legislation up to international standards.

- $\quad$ Insurance supervision could improve in the short run by reprising external auditors to prepare a complementary report, in addition to their annual financial reports. Transferring as soon as possible the responsibility for insurance supervision to INAF is essential.

Appendix II includes the Report on the Observance of Standards and Codes (ROSC) on banking. The ROSC on AML/CFT will be submitted to the Board for information later, once the report of the MONEYVAL mutual evaluation is issued.

The main authors of this AFSSR are Socorro Heysen and Alicia Novoa, with contributions from the rest of the assessment team.

The AFSSR is a summary report on implementation of the indicated financial sector regulatory standards. It has been developed to help jurisdictions identify and remedy weaknesses in financial sector supervision and regulation. The reviews do not directly assess risks such as those associated with asset quality, markets, or fraud that could affect the soundness of financial systems or individual institutions. 


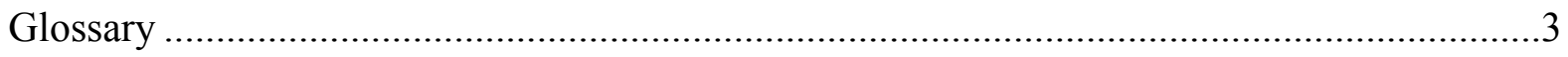

Preface

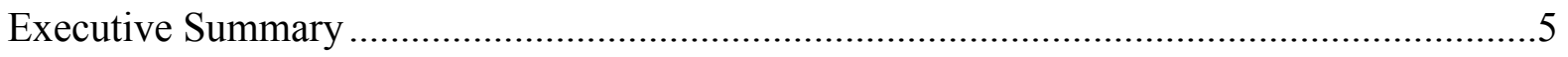

Key Recommendations and Authorities' Response........................................................6

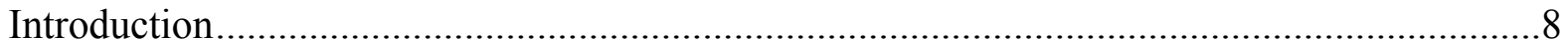

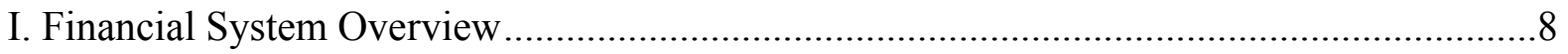

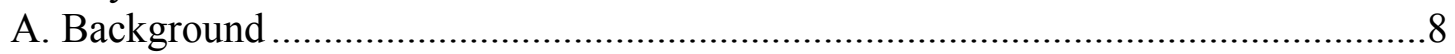

B. Financial Institutions and Markets .................................................................. 11

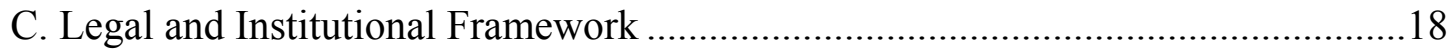

II. Strengths and Vulnerabilities of the Financial Supervisory and Regulatory

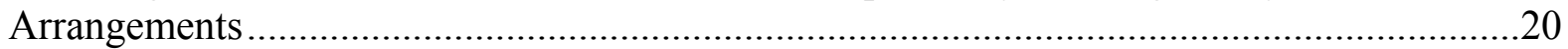

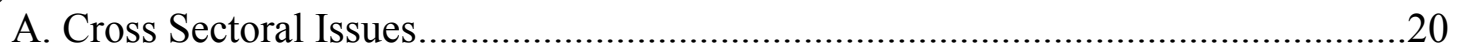

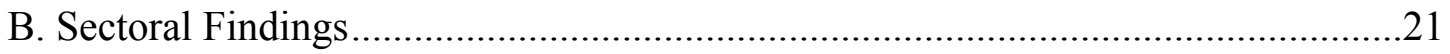

C. Cross-Border Cooperation and Information Exchange ......................................23

Tables

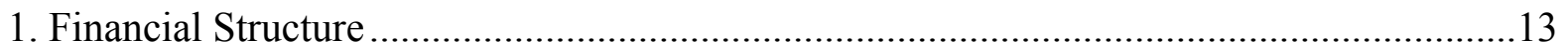

2. Banking System Ownership Structure, as of December 2005 .....................................14

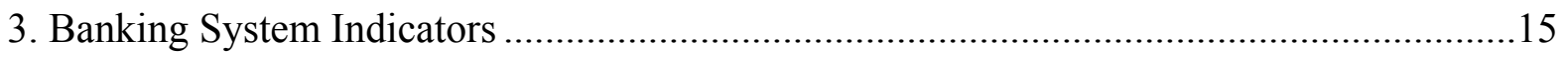

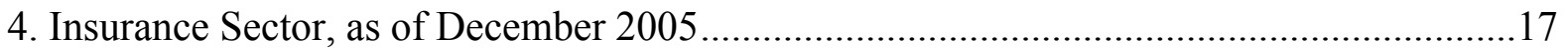

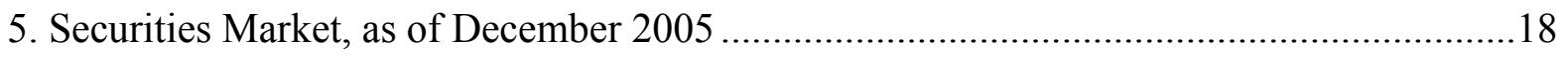

Figures

1. Size of the Banking Sector in Selected Financial Centers, end-2004 ...............................11

2. Deposits, Securities in Custody and Derivatives, as of December 2005 .........................16

Appendices

I. History of the Andorran Banking System

II. Follow up of Implementation of Recommendations Contained in the 2002 Module 2

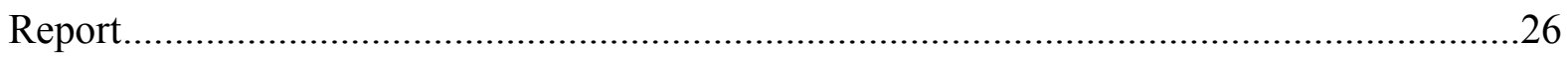

III. Reports on the Observance of Standards and Codes ............................................... 31

Appendix Table

6. Recommended Action Plan to Improve Compliance with the Basel Core Principles .36 


\section{GLOSSARY}

\begin{tabular}{ll} 
ABA & Associació de Bancs Andorrans \\
AML/CFT & Anti-Money Laundering and Combating the Financing of Terrorism \\
BBVA & Banco Bilbao Viscaya Argentaria \\
BE & Bank of Spain (Banco de España) \\
BCP & Basel Core Principles for Effective Banking Supervision \\
CG & Consell General \\
CIS & Collective Investment Schemes \\
CSF & Comissió Superior de Finances \\
EU & European Union \\
IAIS & International Association of Insurance Supervisors \\
IC & Informe Complementario d' Auditoria \\
IFRS & International Financial Reporting Standards \\
INAF & Institut Nacional Andorrà de Finances \\
IOSCO & International Organization of Securities Commissions \\
MONEYVAL & Select Committee of Experts on the Evaluation of AML Measures \\
MF & Ministry of Finance (Ministeri de Finances) \\
ROSC & Report on Observance of Standards and Codes \\
UPB & Unitat de Prevenció del Blanqueig (Laundering Prevention Unit) \\
\hline
\end{tabular}




\section{Preface}

At the invitation of the Andorra government an IMF team visited Andorra from September18-28, 2006 and conducted an assessment of the supervision and regulation of the financial sector. This report is based on work undertaken during the team's visit to Andorra. The current assessment is a follow up to the assessment undertaken in 2002 in the first phase of the Offshore Financial Center (OFC) program. In 2003 the IMF Executive Board agreed that the IMF should conduct periodic assessments (every four to five years) to monitor progress as well as ensure that good supervisory practice has been maintained. ${ }^{1}$

The assessment team comprised Ms. Socorro Heysen (Mission Chief), Ms. Alicia Novoa (both MCM), Mr. Ruben Mendiolaza (Consultant, Superintendency of Banks and Insurance, Peru, Banking), Mr. Walter Zunic (Consultant, Banking), and Mr. Piotr Andrzejewski (Consultant, Insurance and Securities).

The mission met with representatives of the Andorra government including the Cap de Govern, Hon. Albert Pintat; the Minister of Finance Mr. Ferran Mirapeix; the President of the Board of the Institut Nacional Andorrà de Finances (INAF) Mr. Xavier Jordana; the Director General of INAF, Mr. Carles Salvadó; the Head of the Unitat de Prevenció del Blanqueig (UPB) Mr. Jordi Pons; as well as other senior officials, including the Deputy Director General (INAF), Ms. Verónica Guardia; the Director of Supervision (INAF) Ms. Maripau Naranjo and the Director of Tax Administration, Mr. Xavier Jimenez. The mission also met with representatives of various financial institutions, industry associations, audit firms and rating agencies.

The members of the mission would like to express their gratitude to the Andorran authorities and staff of the institutions, which they visited and with whom they worked during their stay for their hospitality and excellent cooperation. In particular the mission would like to thank Mr. Jordi Alcobé and Ms. Esther Canelles for their invaluable logistical support during the mission and the Ministry of Finance (MF) for providing the use of their facilities.

\footnotetext{
${ }^{1}$ See PIN No. 03/138 at http://www.imf.org for a summary of the Executive Board discussion.
} 


\section{EXECUTIVE SUMMARY}

The results of the assessment indicate that financial sector supervision is broadly sound with respect to material activities of the financial system, which are centered on the banking sector. Efforts have been made during the last few years to address several of the recommendations made by the 2002 mission, including by issuing a new charter for the INAF. Work is under way to address the remaining gaps in the regulatory and supervisory framework. Draft laws have been prepared to bring the regulation of the nonbank financial institutions and insurance companies up to international standards, and to strengthen the enforcement capacity of the UPB.

Financial sector supervision in Andorra relies heavily on the work of external auditors who, in addition to the annual financial reports, are required since 2002 to prepare complementary reports. Every year since, INAF has revised the requirements for these reports and has broadened their scope, but additional guidance is needed to ensure that they provide effective support for bank supervision. Clarifying INAF's request and reaching an understanding with auditors on the specific requirements would enhance supervision in the short term. In the medium term, INAF's on-site capacity would be operational and further strengthen supervision.

Andorra has made significant improvements in banking regulation and supervision but additional efforts are needed. Most notably, INAF's independence and ability to cooperate with foreign supervisors has been strengthened by the approval of its new charter. ${ }^{2}$ While INAF's new charter also strengthened its remedial powers, these should be further enhanced by empowering it to undertake all sanctions, including those classified as "very serious." The charter allows INAF to sign agreements with foreign supervisors, but efforts to reach an agreement with the Bank of Spain (BE) have not been successful due to restrictions on the access of supervisors of foreign banks to nominative information of these banks' customers. INAF is able to facilitate nominative information of large exposures and to conduct joint onsite examinations. It is recommended that INAF be also empowered to share with the home country supervisor information about the local operations of the foreign banks necessary to conduct effective supervision of these banks, provided its confidentiality is protected. The development of INAF's on-site supervisory capacity is under way and full on-site inspections are expected to start in late 2007, after the new staff has completed a thorough training program. However, INAF's staff is still lean (12) and additional hirings may be needed to ensure an effective on-site oversight, less reliant on external auditors.

\footnotetext{
${ }^{2}$ The law 14/2003 superseded the original charter issued in 1989 and is referred to as INAF's "charter" hereupon.
} 
The increasing importance of collective investment schemes (CIS) and life insurance raises the need to recast their legislation. It is recommended that the draft law on regulation of CIS be tabled in the Parliament with a view to its adoption as soon as possible. The draft law on insurance regulation may need to be reviewed beforehand. Additionally, short run improvements of insurance supervision could be achieved by enhancing the role of external auditors, requiring additional reports, similar to those in place for other financial sector entities. Transferring the responsibility of insurance supervision to INAF as soon as possible is essential.

The Andorran financial system changed significantly in recent years. The low interest rate environment caused a shift away from deposits and into higher yield instruments offered by various types of asset managers, with a resulting increase of banks' off-balance sheet items. Starting on 2005, the prospect of the retention of EU taxes on the savings income of EU costumers of Andorran banks, induced these customers to switch to savings linked life insurance policies offered by insurance affiliates, thus increasing the significance of the life insurance sector. The sale of the shares of Spanish banks in two of the Andorran banking groups has caused a significant change in the ownership structure. The capital of banks with foreign participation represents 2 percent of total bank capital by end-2006, down from about 70 percent in $2002 .^{3}$

\section{KEy RECOMMENDATIONS AND AUTHORITIES' RESPONSE}

\begin{tabular}{|l|c|l|}
\hline \multicolumn{1}{|c|}{ Recommendation } & Term & \multicolumn{1}{|c|}{ Authorities' Response } \\
\hline Cross Sectoral Issues & ST & $\begin{array}{l}\text { This law is a priority for the MF and } \\
\text { should be approved by the General } \\
\text { Council in the short run }\end{array}$ \\
\hline $\begin{array}{l}\text { Adopt international accounting standards for all the financial } \\
\text { sector, as proposed in draft legislation to be submitted to } \\
\text { Parliament, and adapt prudential rules as necessary }\end{array}$ & ST & $\begin{array}{l}\text { INAF plans to start on-site exams in } \\
\text { late 2007. }\end{array}$ \\
\hline $\begin{array}{l}\text { INAF to develop its capacity for on-site supervision by stepping } \\
\text { up training of new staff and gradually hiring additional staff, as } \\
\text { needed. }\end{array}$ & ST \\
$\begin{array}{l}\text { INAF to clarify requests to external auditors and reach an } \\
\text { understanding of what is expected from them. Hire independent } \\
\text { audit firms to assess the quality of external audit reports, as } \\
\text { needed. }\end{array}$ & $\begin{array}{l}\text { INAF already clarifies its requests to } \\
\text { auditors when necessary and } \\
\text { comments when requests are not } \\
\text { addressed as required. }\end{array}$ \\
\hline $\begin{array}{l}\text { INAF to revisit the frequency of requests made to auditors and } \\
\text { consider options to implement rotation work plans. }\end{array}$ & ST & $\begin{array}{l}\text { INAF will consider implementation } \\
\text { of rotation work plans once INAF's } \\
\text { on-site exams are implemented. }\end{array}$ \\
\hline $\begin{array}{l}\text { Integrate all norms for external auditors into a single body of } \\
\text { rules. }\end{array}$ & ST & $\begin{array}{l}\text { INAF will present this proposal in the } \\
\text { October 2006 meeting with banks and } \\
\text { external auditors. }\end{array}$ \\
\hline
\end{tabular}

\footnotetext{
${ }^{3}$ The actual share of foreign capital in the banking system has fallen from 36 percent to 1 percent from 2002 to end-2006.
} 


\begin{tabular}{|c|c|c|c|}
\hline & Recommendation & Term & Authorities' Response \\
\hline \multicolumn{4}{|c|}{ Banking Regulation and Supervision } \\
\hline & $\begin{array}{l}\text { Full authority to grant and revoke bank licenses based on } \\
\text { technical elements, should be vested in the INAF. }\end{array}$ & MT & $\begin{array}{l}\text { The final authority to grant and } \\
\text { revoke licenses should remain with } \\
\text { the government. }\end{array}$ \\
\hline & $\begin{array}{l}\text { INAF should be empowered to undertake all types of remedial } \\
\text { actions, including issue an orderly resolution of a problem bank } \\
\text { and the revocation of a financial institution's license. }\end{array}$ & MT & $\begin{array}{l}\text { The authorities accept that it's } \\
\text { necessary to strike a balance between } \\
\text { INAF's technical decision and the } \\
\text { approval of the government for } \\
\text { revocation of financial institutions' } \\
\text { license. }\end{array}$ \\
\hline$\bullet$ & $\begin{array}{l}\text { Connected Lending: INAF should ensure that credits to insiders } \\
\text { and related interests are not granted at preferential rates and that } \\
\text { transactions to insiders, such as credits to the members of a bank's } \\
\text { Board of Directors, are required to be approved by the Board. }\end{array}$ & ST & $\begin{array}{l}\text { INAF is considering issuing a } \\
\text { communication on this matter. }\end{array}$ \\
\hline$\bullet$ & $\begin{array}{l}\text { INAF should intensify its efforts to enter into a formal agreement } \\
\text { with the banking authorities of foreign supervisors that will allow } \\
\text { full compliance of Andorra as a home and host country } \\
\text { supervisor. The INAF should share with the home country } \\
\text { supervisor information about the local operations of the foreign } \\
\text { banks, provided its confidentiality is protected. }\end{array}$ & ST & $\begin{array}{l}\text { The authorities reaffirm their } \\
\text { intention to enter into a formal } \\
\text { agreement with the banking } \\
\text { authorities of foreign banks. }\end{array}$ \\
\hline \multicolumn{4}{|c|}{ Regulation and supervision of Collective Investment Schemes } \\
\hline$\bullet$ & $\begin{array}{l}\text { Review the draft law on CIS to: (i) ensure proper and disclosed } \\
\text { basis for asset valuation, pricing and redemption; and } \\
\text { (ii) strengthen provisions on disclosure to allow evaluation of the } \\
\text { suitability of a CIS for a particular investor. }\end{array}$ & ST & $\begin{array}{l}\text { The authorities intend to work on this } \\
\text { as soon as possible. }\end{array}$ \\
\hline$\bullet$ & $\begin{array}{l}\text { The government should table the draft law on CIS in the General } \\
\text { Council with a view to its adoption as soon as possible. }\end{array}$ & MT & $\begin{array}{l}\text { Draft laws have been sent to the } \\
\text { financial sector entities for } \\
\text { comments. This law is a priority for } \\
\text { the government. }\end{array}$ \\
\hline \multicolumn{4}{|c|}{ Regulation and Supervision of Insurance Companies } \\
\hline$\bullet$ & $\begin{array}{l}\text { The MF should require external auditors to produce a } \\
\text { complementary report on policies, systems and processes of } \\
\text { insurance companies, including internal controls, and strengthen } \\
\text { its oversight capacity. }\end{array}$ & ST & $\begin{array}{l}\text { Efforts will be concentrated to } \\
\text { implement this recommendation in } \\
\text { the short term. }\end{array}$ \\
\hline$\bullet$ & $\begin{array}{l}\text { Transfer the responsibility for supervision of insurance companies } \\
\text { to INAF with sufficient supervisory staff to carry out this } \\
\text { responsibility. }\end{array}$ & MT & $\begin{array}{l}\text { Once the new insurance law is } \\
\text { approved, this responsibility will be } \\
\text { carried out by INAF. }\end{array}$ \\
\hline$\bullet$ & $\begin{array}{l}\text { A new insurance law should be tabled in the General Council, } \\
\text { codifying, inter alia, prudential requirements and requirements } \\
\text { with regards to internal controls, conduct of business, policy } \\
\text { holder protection, public disclosure and international cooperation } \\
\text { requirements. }\end{array}$ & MT & $\begin{array}{l}\text { The MF will prepare a draft law } \\
\text { during 2006, in conformity with the } \\
\text { International Association of } \\
\text { Insurance Supervisors (IAIS) } \\
\text { principles. This law is a priority for } \\
\text { the MF. }\end{array}$ \\
\hline
\end{tabular}




\section{INTRODUCTION}

1. An IMF team conducted an evaluation of the regulation and supervision of the financial system. The team:

- $\quad$ Assessed bank regulation and supervision based on the compliance with the Basel Core Principles for Effective Banking Supervision (BCP);

- $\quad$ Reviewed the regulatory and supervisory framework for the insurance sector, but given its small size, an assessment of compliance with IAIS principles was not conducted;

- $\quad$ Reviewed the regulatory and supervisory framework for CIS on the basis of the corresponding section of the International Organization of Securities Commissions (IOSCO) standards, but an assessment of compliance of these standards was not conducted; and

- $\quad$ Reviewed the overall arrangements and practices for cross-sector and cross-border cooperation and information exchange.

2. In addition the report includes an initial review of anti-money laundering and combating the financing of terrorism (AML/CFT) practices conducted on the basis of information provided by the authorities and discussions with UPB and INAF senior staff. The mission had access to the preliminary results of the mutual evaluation conducted by the Select Committee of Experts on the Evaluation of Anti-Money Laundering Measures (MONEYVAL) in October 2005, but a ROSC on compliance with AML/CFT standards will only be prepared once the final results of this evaluation are issued, in mid-2007, according to the authorities' expectations.

3. The mission evaluated the degree to which the authorities have implemented recommendations contained in the 2002 Module 2 report. In addition, the mission discussed with the authorities the details of Andorra's participation on the Information FrameworkFinancial Activities in International and Offshore Financial Centers. The authorities have agreed to participate in this initiative, and expect to submit annual information by early 2007.

\section{FinANCiAL SySTEM OVERVIEW}

\section{A. Background}

\section{History of Andorra's offshore financial center}

4. Andorra's financial system is relatively young. The first bank-Banc Agrícoli Comercial d'Andorra - was established in 1930 to service the local population and the Spanish immigrants working at the recently established Hydroelectric Company. At that time 
Andorra's economy was essentially dedicated to agriculture and commerce. During the next two decades, Andorra's banking system serviced this population by taking deposits and granting loans to finance agriculture and commerce, and its expansion was rather limited. Andorra emerged as a regional financial center during the 1950s, when Spain experienced a period of capital flight and Andorra eliminated all taxes on banking operations (1951). Capital inflows mostly from the Catalunya region fostered the expansion of the banking sector. Most of Andorra's currently existing banks were created during that decade (Appendix I).

5. The banking system was self-regulated until 1993, when the financial system law was issued and the Institut Nacional Andorrà de Finances (INAF) was established as a technical institution to supervise financial companies and to propose to the government the regulations pertaining to the financial system. Until then the Andorran Bankers' Association (ABA), created in 1960, had effectively acted as a self-regulatory body, issuing guidelines that were followed by Andorran banks.

6. Throughout its 75 years of banking history, Andorra has not experienced a banking crisis. One banking institution failed in 1968 (Sobanca), and the remaining banks stepped up to honor its liabilities in order to preserve the confidence in the system. Andorran banks have traditionally maintained high levels of liquidity and capital as a way to signal their capacity to overcome problems in the absence of regulation and supervision. However, this prudent behavior remained generally unchanged after regulation and supervision were implemented.

\section{Previous assessments}

7. The 2002 report covered an assessment of compliance with BCP and with AML/CFT standards, as well as a review of the insurance and securities sectors. The assessment concluded that supervision in Andorra was generally adequate with respect to material activities of the financial system, although the report provided several areas for improvement. ${ }^{4}$ It was noted that Andorra had a high level of compliance with the $\mathrm{BCP},{ }^{5}$ which represented around 95 percent of all financial sector activities. A high level of compliance with international standards for AML was also found. Given the limited size of the insurance and securities systems relative to the overall financial system, full assessments of compliance with the IAIS and the IOSCO standards were not carried out.

8. In order to improve compliance with international standards for banking supervision, the assessors recommended to: (i) clarify responsibilities and strengthen the autonomy of the agency responsible for bank supervision, the INAF; and (ii) improve cooperation and

\footnotetext{
${ }^{4}$ Andorra: Assessment of the Supervision and Regulation of the Financial Sector, August 2002.

${ }^{5}$ Compliance was found in 14 principles, large compliance in 13 principles, material noncompliance in 2 principles, and 1 principle was deemed not applicable.
} 
exchange of information with the home supervisor of subsidiaries of foreign banks. The independence of INAF was limited by the requirement for prior approval and/or consent of the finance minister and the Comissió Superior de Finances (CSF) for virtually all actions of INAF, including approval of regulation, administrative sanctions and authorization of on-site inspections by INAF. In turn, cooperation with home supervisors of foreign banks was restricted by limits on the ability of INAF to enter into agreements with foreign supervisors and limits on the ability of foreign supervisors to conduct on site examinations (see Appendix II for details).

9. The 2002 report found the regulatory framework for insurance, based on a 1989 law, to be in need of improvement on the supervisory arrangement, prudential regulation and international cooperation. It was recommended that: (i) supervision of insurance be included within the functions of INAF, which will entail a modification to the insurance law and other enabling legislation; (ii) that INAF work to develop a common chart of accounts for insurance providers (e.g., companies and delegations); and (iii) that INAF define complementary audit instructions for external auditors in a manner consistent with actions taken for banks. Regarding collective investment funds and other asset management activities, the assessors recommended that securities legislation, then in the process of being drafted, bolster INAF's mandate for protecting investors and promoting market transparency.

10. The mission found that the authorities have implemented many of the 2002 recommendations on banking regulation and supervision, but are yet to implement most of the recommendations on the insurance and securities sectors. The charter of INAF, approved in 2003, strengthens INAF's independence and capacity for cross-border cooperation and information exchange. Since then, INAF has issued additional information and evaluation requirements for banks' external auditors (Informe Complementari d' Auditoria), increased the number of supervisory staff with four new hirings, started to train inspectors in order to commence some onsite inspections toward the end of 2007 and, taken steps to seek agreements with foreign supervisors. Legislation to establish the framework for the operation of investment funds managers and other asset managers has been drafted but is yet to be submitted to Parliament for approval. A new insurance law has been drafted but not tabled in the previous legislature.

11. INAF's independence has been strengthened by (i) establishing it as the authority responsible for the Andorran financial system and suppressing the role of CSF as a superior authority; (ii) establishing a clear process for the approval by Congress of INAF's budget; (iii) allowing INAF to conduct on-site examinations as needed, without any prior approval; and (iv) allowing it to issue all types of sanctions, with the exception of those graded as very serious, which are issued by the MF, at the proposal of the INAF. Additionally, this charter allows INAF to enter into agreements with foreign supervisors. 


\section{B. Financial Institutions and Markets}

12. Compared with other jurisdictions that provide financial services, Andorra is a small financial center (Figure 1) dominated by banks. The financial services sector produces 15 percent of GDP and employs some 1,523 persons accounting for 3.6 percent of all jobs as of 2005. It is the highest paying sector in the Andorran economy, with average salaries above twice the national average.

Figure 1. Andorra: Size of the Banking Sector in Selected Financial Centers, end-2004 1/ 2/

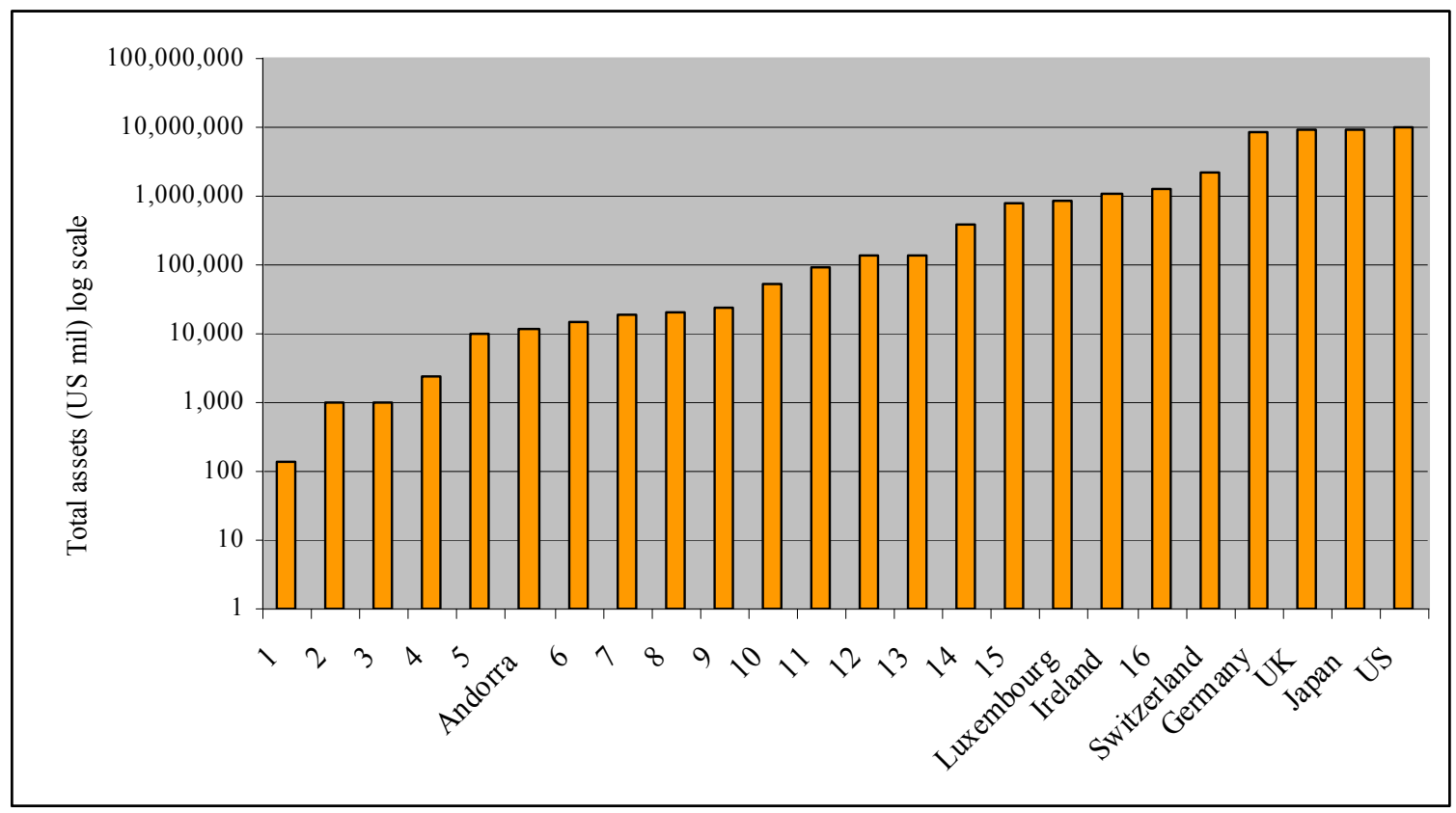

Source: Data submitted for the Information Framework initiative and country authorities.

1/ The jurisdictions reporting under the initiative have been numbered in order of banking asset size. Numbered jurisdictions provided data to the Fund on a confidential basis. Data on named jurisdictions were obtained from public sources.

2/ The data have been plotted on a logarithmic scale because of the wide dispersion in asset size among jurisdictions.

13. The financial system comprises 7 banking institutions, 1 specialized financial credit institution, 7 collective investment entities, 4 wealth management companies and 28 insurance companies, 15 of which are branches of foreign insurance companies authorized to operate in Andorra. The 7 banks operating in Andorra are part of 5 banking groups. These banking groups generally own 1 collective investment entity and a life insurance company. Andorran banks can only own up to 25 percent of nonlife insurance companies and most banks do so. However, the shareholders of one of the banks have a participation in a nonlife insurance company besides the shares held directly by the bank; so this banking group effectively controls fully a nonlife insurance company. Bank related entities conduct 99 percent of the life insurance business (measured by gross premiums) and 99 percent of the 
collective investment business. In sum, the financial system is dominated by banking groups that control all the institutions accounting for the quasi-totality of their markets.

14. The Andorran financial sector has experienced significant changes over the past five years (Table 1). First, as in other jurisdictions, the low interest rate environment caused a shift in customer's portfolios, away from bank deposits and into financial instruments offering higher returns and asset management, with the obvious consequence of shifting onbalance sheet to off-balance sheet products. In this context, bank deposits remained mostly flat, while assets managed by banks and collective investment entities grew by 12.8 , and 16.0 percent yearly average respectively from 2000 to 2005. Second, since July 2005 Andorra started the retention of EU taxes on savings income earned by EU residents. ${ }^{6}$ The prospect of higher taxes induced EU customers of Andorran banks to seek alternatives to savings instruments by moving into other financial instruments, including life policies offered by life insurance companies controlled by Andorran banks. As a result, life insurance premiums grew from 61 million euros in 2004 to 1.8 billion euros in 2005 .

\section{Banking system}

15. The Andorran banking system is small and highly concentrated. Andorra has 7 licensed banks which offer traditional banking services through a network of about 55 branches, including both locally and foreign owned entities. Banking total assets and customer deposits amounted to 11.3 billion euros and 9.3 billion euros in 2005, respectively, About 2.7 billion euros out of 8.9 billion euros of total loans in 2005 were loans to nonresidents ${ }^{8}$ mostly from Europe and North America, and a significant share of deposits from nonresidents, primarily from the European Union (EU). ${ }^{9}$ Andorran banks have branches in Bahamas and Uruguay and a representative office in Panama, but these operations represent a very small share of the business of the banking groups.

16. The system is based on a universal banking model, without losing sight of specialized banking services. Andorran banks can, therefore, offer all banking services, including credit operations, asset management and investment counseling, liability operations (current, savings and term accounts), stock transactions, financial analysis and other banking services (credit cards, transfers, standing orders, etc.). Insurance companies controlled by banks also carry out the majority of the life insurance business.

\footnotetext{
${ }^{6}$ EU Directive 2003/48. Tax retention of 15 percent of savings income earned by EU residents applies from July 1, 2005. The tax rate increases to 20 percent on July 1, 2008 and to 35 percent on July 1, 2011.

${ }^{7}$ The 2005 premiums include the transfer of assets into capitalization schemes, an event that is not likely to be repeated in 2006.

${ }^{8}$ The remainder were loans to residents.

${ }^{9}$ Figures on resident and non resident deposits are expected to be available starting on 2007.
} 
Table 1. Andorra: Financial Structure

(In millions of euros)

\begin{tabular}{|c|c|c|c|c|c|c|}
\hline \multirow[b]{2}{*}{ Sector } & \multirow[b]{2}{*}{2000} & \multirow[b]{2}{*}{2003} & \multirow[b]{2}{*}{2004} & \multirow[b]{2}{*}{2005} & \multicolumn{2}{|c|}{$\begin{array}{c}\text { Annual Growth } \\
\text { Rates } \\
\end{array}$} \\
\hline & & & & & $05 / 04$ & $05 / 00$ \\
\hline \multicolumn{7}{|l|}{ Banks } \\
\hline Number & 8 & 8 & 7 & 7 & & \\
\hline Banks Assets & 11,252 & 10,078 & 10,061 & 11,328 & 12.6 & 0.1 \\
\hline Loans & 9,378 & 7,878 & 8,006 & 8,921 & 11.4 & -1.0 \\
\hline $\operatorname{Deposits}^{1}(1)$ & 9,565 & 8,177 & 8,114 & 9,289 & 14.5 & -0.6 \\
\hline Assets under Management (2) & 10,541 & 14,301 & 16,383 & 19,235 & 17.4 & 12.8 \\
\hline $\begin{array}{l}\text { Total Assets under } \\
\text { Management }(1)+(2)\end{array}$ & 20,106 & 22,478 & 24,496 & 28,524 & 16.4 & 7.2 \\
\hline \multicolumn{7}{|l|}{ Collective Investment Schemes } \\
\hline \multicolumn{6}{|l|}{ Number of CIS } & \\
\hline Number of Funds & 94 & 127 & 142 & 158 & 11.3 & 10.9 \\
\hline Private Funds & 85 & 109 & 113 & 125 & 10.6 & 8.0 \\
\hline Public Funds & 9 & 18 & 29 & 33 & 13.8 & 29.7 \\
\hline Total Assets under Management & 4,039 & 5,991 & 7,829 & 8,495 & 8.5 & 16.0 \\
\hline Private Funds & 3,049 & 4,382 & 5,308 & 6,716 & 26.5 & 17.1 \\
\hline Public Funds & 990 & 1,609 & 2,521 & 1,779 & -29.5 & 12.4 \\
\hline \multicolumn{7}{|l|}{ Private Asset Managers } \\
\hline Number & 4 & 4 & 4 & 4 & & \\
\hline Total Assets under Management & & n.a. & 215 & 274 & 27.4 & \\
\hline \multicolumn{7}{|l|}{ Insurance Companies 2/ } \\
\hline Total Assets (Life + Nonlife) & 163.5 & 178.0 & 418.2 & 2036.4 & 386.9 & 65.6 \\
\hline \multicolumn{7}{|l|}{ Life } \\
\hline Number & 7 & 7 & 7 & 8 & & \\
\hline Gross Premiums & 17 & 42 & 61 & 1758 & 2763.7 & 151.7 \\
\hline Net premiums & 14 & 28 & 47 & 1739 & 3607.8 & 163.7 \\
\hline \multicolumn{7}{|l|}{ Nonlife } \\
\hline Number & 20 & 20 & 20 & 20 & & \\
\hline Gross Premiums & 35 & 51 & 60 & 50 & -16.5 & 7.6 \\
\hline Net premiums & 28 & 40 & 43 & 38 & -11.1 & 6.4 \\
\hline
\end{tabular}

Source: Institut Nacional Andorrà de Finances and Ministry of Finance.

$1 /$ Includes costumer deposits and deposits from financial institutions.

2/ Insurance companies that conduct both life and nonlife business are listed under the predominant sector. 
17. The system has significant links to Spain, albeit these links have decreased. With the sales of BBVA's participation in the Inter-Mora bank to the Andorran shareholders in early 2006, currently, only three of the seven banks authorized to operate in Andorra have Spanish participation. These banks account for about 45 percent of assets and deposits of the banking system, down from around 71 percent in 2001. In September 2006, the Caixa d'Estalvis i Pensions de Barcelona (la Caixa) announced the sale of its shares in Credit Andorra to the Andorran shareholders of this bank. Once this operation is finalized only one Spanish Bank, amounting to about 4 percent of assets and deposits of the banking system will remain operating in Andorra ${ }^{10}$ (Table 2).

Table 2. Andorra: Banking System Ownership Structure, as of December 2005

(In millions of euros)

\begin{tabular}{|c|c|c|c|c|c|c|c|c|}
\hline $\begin{array}{l}\text { Banks by } \\
\text { Controlling } \\
\text { Shareholder }\end{array}$ & Assets & $\begin{array}{l}\text { Percent } \\
\text { of } \\
\text { Total }\end{array}$ & Deposits & $\begin{array}{l}\text { Percent } \\
\text { of } \\
\text { Total }\end{array}$ & Capital & $\begin{array}{l}\text { Percent } \\
\text { of } \\
\text { Total }\end{array}$ & Employees & $\begin{array}{c}\text { Percent } \\
\text { of } \\
\text { Total }\end{array}$ \\
\hline Majority Andorran & 6,273 & 55.4 & 5,211 & 56.1 & 701 & 52.6 & 664 & 57.7 \\
\hline Andbanc & 2,084 & 18.4 & 1,648 & 17.7 & 333 & 25.0 & 283 & 24.6 \\
\hline Banc Internacional 1/ & 2,189 & 19.3 & 1,820 & 19.6 & 203 & 15.2 & 227 & 19.7 \\
\hline $\begin{array}{l}\text { Banca Mora 2/ } \\
\text { Banca Privada }\end{array}$ & 1,123 & 9.9 & 996 & 10.7 & 100 & 7.5 & - & - \\
\hline d'Andorra & 877 & 7.7 & 747 & 8.0 & 66 & 4.9 & 154 & 13.4 \\
\hline $\begin{array}{l}\text { With Spanish } \\
\text { participation }\end{array}$ & 5,055 & 44.6 & 4,078 & 43.9 & 631 & 47.4 & 486 & 42.3 \\
\hline CaixaBank & 1,022 & 9.0 & 819 & 8.8 & 142 & 10.6 & 126 & 11.0 \\
\hline Credit Andorra & 3,578 & 31.6 & 2,858 & 30.8 & 459 & 34.5 & 284 & 24.7 \\
\hline Banc Sabadell & 455 & 4.0 & 402 & 4.3 & 30 & 2.3 & 76 & 6.6 \\
\hline Total banking system & 11,328 & 100.0 & 9,289 & 100.0 & 1,333 & 100.0 & 1,150 & 100.0 \\
\hline
\end{tabular}

Source: Institut Nacional Andorrà de Finances.

1/ Banc Internacional has majority Andorra ownership since March 2006.

2/ Banca Mora is fully owned by Banc Internacional and information on employees corresponds to the total for both banks.

18. The significant change in ownership structure poses challenges for both, the banks and the INAF. While the new shareholders of Credit Andorra have made clear their intention to maintain the high risk management standards, the INAF needs to be specially vigilant to

${ }^{10}$ Since 2005 Credit Andorra owns 100 percent of Caixa Bank. 
ensure that all banks are prepared to adequately manage the potential risks, including the possibility that the customer base of some Andorran banks contracts after the change in ownership structure. The authorities and the banks' representatives regard this risk as unlikely.

19. The banks are highly capitalized and liquid, far beyond the minimum 10 percent $^{11}$ and 40 percent $^{12}$ required by prudential regulations (Table 3 ). Profits are strong and have improved over time due, mainly, to higher fees and commissions income, which reflects the shift to off-balance sheet activities. Most nonbank credit exposure remains to the domestic economy, with a loan-to-deposit ratio high at 96 percent and 76 percent of total loans granted to Andorran residents.

Table 3. Andorra: Banking System Indicators

(In percent)

\begin{tabular}{lrrrr}
\hline & 2000 & 2003 & 2004 & 2005 \\
\hline & & & & \\
Capital Adequacy Ratio & 32.3 & 32.4 & 31.7 & 28.8 \\
Return on Asset & 2.8 & 2.8 & 3.1 & 3.4 \\
Return on Equity & 26.2 & 19.8 & 20.0 & 21.4 \\
Liquid assets over total assets 1/ & 45.2 & 46.4 & 40.7 & 36.2 \\
Liquidity ratio 2/ & 84.0 & 77.0 & 75.1 & 66.2 \\
Fees and commissions as & & & & \\
a percent of total revenue & 25.8 & 38.6 & 44.3 & 45.1 \\
\hline
\end{tabular}

Source: Institut Nacional Andorrà de Finances.

$1 /$ Assets maturing in less than one month are considered liquid.

2/ Liquid assets in percent of short term liabilities

20. A significant increasing portion of off-balance sheet items is mainly driven by the growth of securities and other instruments in custody (16.2 percent growth in 2005) and derivatives operations (61.1 percent growth in 2005). Securities in custody amounted to 20.4 billion euros in 2005 , nearly thrice the amount of costumer deposits, and derivatives operations amounted to 10.8 billion euros (Figure 2). Bank managed third party' assets and assets of investment funds held in custody by banks amounted to 19.2 billion euros. The significant growth of derivatives operations corresponds to currency hedging instruments to cover customers' exposure to currency risk. Parallel to this pattern there has been a slow decline of on-balance sheet items.

\footnotetext{
${ }^{11}$ Minimum Capital to Risk Weighted Assets (CAR) as defined in Basel 1.

${ }^{12}$ Andorran banks are required to hold liquid assets for at least 40 percent of short-term liabilities.
} 
Figure 2. Andorra: Deposits, Securities in Custody, and Derivatives, as of December 2005 (In millions of euros)

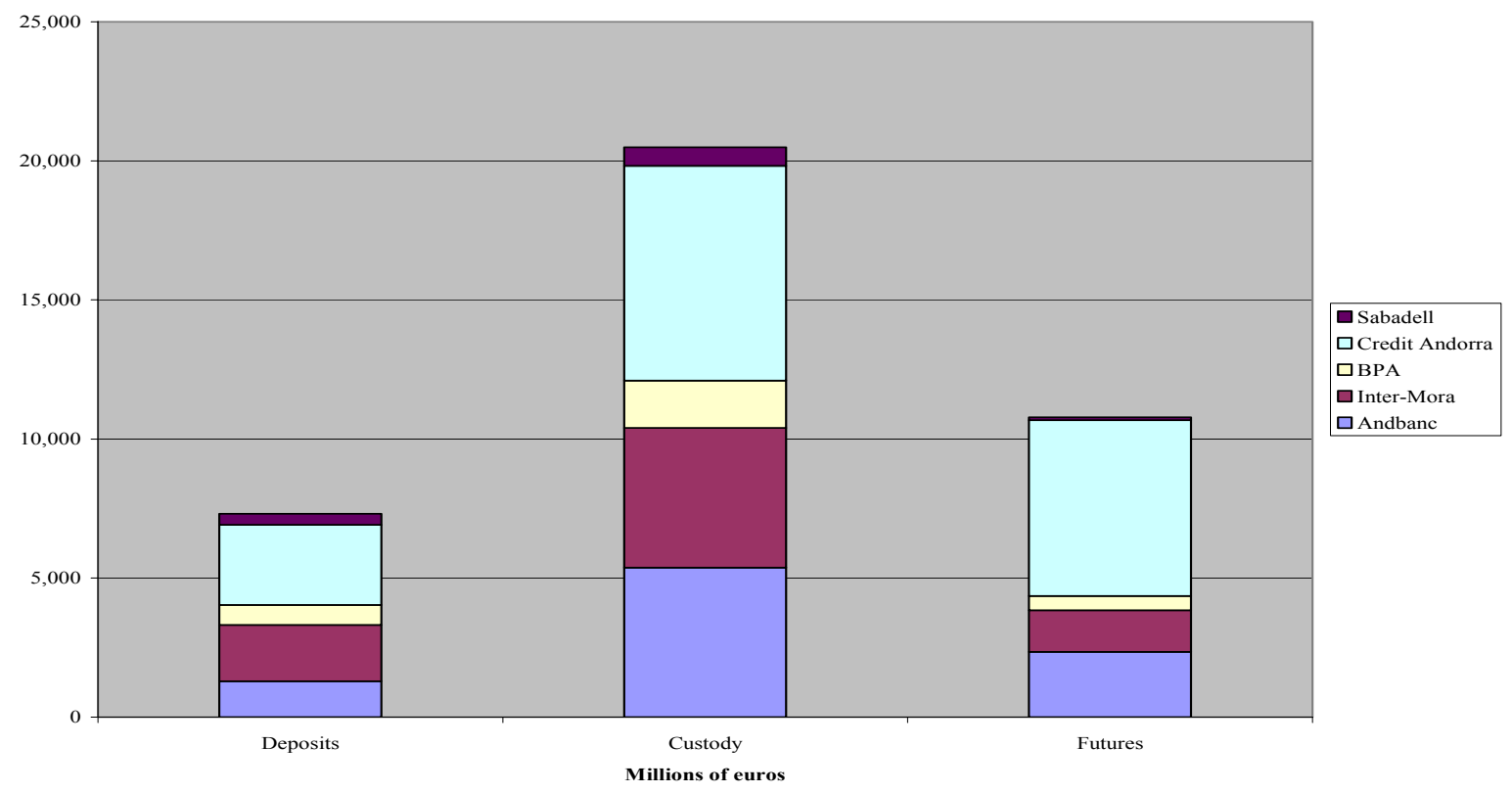

Source: Institut Nacional Andorrà de Finances.

\section{Insurance sector}

21. The insurance sector is small relative to the banking sector. The core insurance activity is comprised of a local market for nonlife business and a life insurance segment. Insurance business has traditionally been largely confined to activities conducted with Andorran residents. The home market -70000 residents — while prosperous, is small and reportedly close to saturation. However, since 2005 , life insurance business is picking up and a nonresident life insurance segment has emerged as, in advance of the entry into force of the EU Directive on the Taxation of Savings, funds were transferred from bank deposits to life insurance contracts integrating a savings component.

22. Aggregate gross premiums written, life, and nonlife insurance, were over 1.8 billion euros in 2005 (Table 4). This was an unusual year, as the significant transfer of funds from banks to insurance companies resulted in a substantial, one time, increase in life insurance gross premiums written to close to 1.8 billion euros in 2005. In 2004, a "normal" year, life insurers (premiums of 61.5 million euros) and nonlife insurers (premiums of 60.5 million euros) shared the market equally. While Andorran insurers conduct no direct business abroad, if the 2005 performance in life insurance sets off a trend, an important nonresident segment of the domestic market is likely to develop. Reinsurance, not available locally, is usually contracted with key international reinsurers. 
23. Life insurance products are primarily sold through Andorran companies, controlled by Andorran banks. Nonlife products are sold through nonbank Andorran companies or through branches of foreign insurance companies, primarily from France and Spain. In 2005, there were seven life insurance companies, all controlled by Andorran banks, and six nonlife insurers, one of them controlled by a banking group and its shareholders. There were also 15 branches of foreign insurers, covering about half of the nonlife insurance market. There are no insurance groups in Andorra.

Table 4. Andorra: Insurance Sector, as of December 2005

(In millions of euros)

\begin{tabular}{lrrr}
\hline & $\begin{array}{c}\text { Gross Premiums (2005) } \\
\text { Mill Euros }\end{array}$ & $\begin{array}{c}\text { Number } \\
\text { of } \\
\text { companies }\end{array}$ \\
\hline Life Insurance & $1,758.1$ & 100.0 & \\
Companies related to Andorran Banks & $1,739.8$ & 99.0 & 6 \\
Other Andorran companies & 12.9 & 0.7 & 1 \\
Branches of Foreign Insurance companies & 5.3 & 0.3 & 1 \\
Nonlife Insurance & & & \\
Companies related to Andorran Banks & 50.4 & 100.0 & \\
Other Andorran companies 1/ & n.a. & n.a. & 0 \\
Branches of Foreign Insurance companies & 26.3 & 52.2 & 6 \\
\hline
\end{tabular}

Source: Andorra Ministry of Finance.

1/ Includes an Andorran insurance company controlled by shareholders of a banking group.

\section{Securities markets and collective investment schemes}

24. Andorra has no stock exchange and its securities activities are highly integrated with the banking activities. Activities are limited to funds management and investments carried out by banks and collective investment management firms (Table 5). Private asset management firms are also present, though the volume they operate is very low (about 274 million euros in 2005). Most of the investment services in the principality are provided by banks. The investment service sector includes seven managers of CIS and four private asset management firms. These are regulated by the financial system law and supervised by INAF, but there is no legislation specific to securities, laws of general application and INAF directives apply. 
Table 5. Andorra: Securities Market, as of December 2005

(In millions of euros)

\begin{tabular}{|c|c|c|c|c|}
\hline & 2000 & 2003 & 2004 & 2005 \\
\hline Number of Funds & 94 & 127 & 142 & 158 \\
\hline \multicolumn{5}{|l|}{ Of which, } \\
\hline Public & 85 & 109 & 113 & 125 \\
\hline Private & 9 & 18 & 29 & 33 \\
\hline $\begin{array}{l}\text { Total Assets of } \\
\text { Funds }\end{array}$ & 4,039 & 5,991 & 7,829 & 8,495 \\
\hline \multicolumn{5}{|l|}{ Of which, } \\
\hline Public & 3,049 & 4,382 & 5,308 & 6,716 \\
\hline Private & 990 & 1,609 & 2,521 & 1,779 \\
\hline
\end{tabular}

Source: Institut Nacional Andorrà de Finances.

\section{Legal and Institutional Framework}

25. The INAF is the supervisor for the financial sector, including banks and nonbank financial companies, while insurance supervision is the responsibility of the MF. The UPB, created in 2001, has exclusive jurisdiction over money laundering investigations and supervision in Andorra.

26. The INAF is a public financial institution established in 1989 with legal personality, and operational and budgetary independence, according to a new charter passed in 2003. The INAF is under the direction of a Consell d'Administració, a Board of six members appointed by the principality's Consell General (CG) at the proposal of the MF, for a period of six years, half of which have terms staggered every three years. In addition, the Institute has a Director General — appointed by the government—and a Deputy Director General who have a six-year term.

27. The INAF has direct responsibility for the ongoing supervision of the financial system, except the insurance sector, and the day-to-day monitoring of the condition of all financial institutions, and has powers to carry out these responsibilities. It can, for instance, issue mandatory directives (Comunicats), access all information necessary to conduct its work, conduct on-site examinations, impose corrective actions and sanctions on supervised entities and enter into agreements with foreign supervisors. However, the INAF does not make the final decision with regards to granting and revoking licenses in the financial sector or to imposing sanctions graded as very serious, which are a responsibility of the MF. While the MF has effectively followed the INAF's advise and these limitations have so far not caused problems in Andorra, it would be advisable to empower the INAF to make these decisions. Aligning the entry, sanctioning and exit decisions with the responsibility for 
supervision in the financial system, would allow the government to establish a stronger and clearer accountability framework.

28. The legal framework for financial institutions, excluding the insurance sector, is based on five main laws of general application to the financial sector. These are: (i) the law regulating the financial system (1993); (ii) the law governing the operational powers of the various components of the financial system (1996); (iii) the law governing the disciplinary system of the financial sector (1997); (iv) the law regulating the basic administrative rules of the banking institutions (1998); and (v) the charter of the INAF (2003). These laws have been supplemented by the INAF directives (Comunicats), which contain fiduciary, prudential and conduct of business requirements and govern the supervision of bank and non bank financial institutions. Draft laws updating the regulatory framework for non bank financial institutions have been elaborated by the INAF. These draft laws transpose the provisions of existing directives of the INAF and strengthen them by including provisions inspired on legislation recently promulgated in key foreign jurisdictions. The new law would contain comprehensive and detailed provisions on company establishment, evolution and closing; accounting, auditing and reporting; fiduciary and prudential duties, business conduct and regulatory and market disclosure and supervision. The CIS draft law appears to be Euro-compatible, in particular as regards the EU Markets in Financial Services Directive ${ }^{13}$ and the related EU legislation. Reportedly, these bills are to be tabled soon in the General Council (Parliament).

29. There is consensus that the legal framework for the insurance sector requires substantial renewal, in line with EU regulations and the principles of the IAIS. Currently, this sector is solely regulated by a 1989 Law (Llei de regulació de l'actuació de les companyies $d$ 'assegurances al Principat). No prudential or conduct of business regulations have been issued to supplement this law. It should be noted that the charter of the INAF mandated presentation in early 2004 to the Parliament of regulations for the integration of insurance supervision in INAF. ${ }^{14}$ A law on regulation of insurance was drafted in late 2003. It requires however, a substantive review to make it consistent with the IAIS principles before it is tabled in Parliament. Reportedly, this is among the legislative priorities of the new government.

30. Financial institutions, with the exception of insurance companies, follow accounting rules issued by INAF. The Chart of Accounts -Pla Comptable- was issued in 1999 and became mandatory for the first time for fiscal years ended December 2000. These accounting rules were inspired by the Spanish prudential rules in force at the time. A revision is merited in the context of the International Financial Reporting Standards (IFRS), now in use by all major financial centers in Europe. There are no accounting standards mandated for insurance

${ }^{13}$ Directive 2002/87/EC of the European Parliament and the Council of December 16, 2002.

${ }^{14}$ INAF Law, Second transitional provision. 
companies in Andorra. The uneven implementation of accounting practices creates problems of comparability of financial statements within the insurance sector. An accounting draft law is being studied by the government, with the aim to adopt and implement IFRS in all Andorran companies. A draft law is expected to be ready for submission to Parliament in 2007. INAF is in favor of all banks adopting IFRS as soon as the draft legislation is passed by the CG and to adapt prudential regulations as needed to narrow the accounting choices made available to banks by the international accounting standards.

\section{STRENGTHS AND VULNERABILITIES OF THE FinANCIAL SUPERVISORY AND REgULATORY ARRANGEMENTS}

\section{A. Cross Sectoral Issues}

\section{The role of external auditors in the financial system oversight}

31. The effectiveness of the INAF supervision is highly dependent on the work of external auditors. The INAF is currently developing its on-site supervisory capabilities, which are to be operational by end-2007, once training of new its staff is completed. In the meantime, this function is carried out by external auditors. Even with the new hirings, INAF's staff is very lean (12), and additional hirings are recommended to implement an effective on-site oversight function, that relies less on the external audit firms to conduct complementary audits on its behalf.

32. Detailed INAF directives require external auditors to make an evaluation of a wide range of areas, which are reported annually in the IC. These areas include: (i) compliance with accounting and prudential rules; (ii) report of significant events; (iii) consolidation of financial statements; (iv) organization and management; (v) internal control processes; (vi) validation of prudential reports filed with the INAF; (vii) management of credit, market, liquidity, country, operational, and legal risks; (viii) follow up of issues raised in previous reports; and (ix) general conclusion and recommendations. The IC has been in effect since year 2001 for banks, and since 2005 for nonbank financial institutions. In a tripartite meeting carried every October by INAF senior staff, with the external auditor and the bank management, the IC is discussed and corrective measures are required if INAF deems they are needed.

33. It appears that supervisory expectations laid out in the requests of the IC do not always match those of external auditors'. Auditors have indicated to mission staff that to opine on some themes (i.e., internal controls and risk management controls, assessment and management of market and operational risks, structured products and derivatives, adequacy of an entity's administrative structure, etc.) they would require benchmarks or best practices defined by the supervisor to which contrast the banks' current practices against; and that, further, their understanding was that they were not to provide an opinion about each one of the areas for which the supervisor had a request in the IC. Several IC read by the mission and discussions conducted with several international audit firms indicate that, in some instances, 
auditors limited their work to verify that the entity complied with its policies and procedures without necessarily assessing whether these are adequate. Moreover, some external auditors of non bank financial entities stated to the mission that they provided the information requested in the IC based solely on the audit work conducted during the annual audit of the entity's financial statements.

34. In order to enhance the effectiveness of the work conducted by external auditors, it is recommended that INAF: (i) integrate dispersed audit regulations into a single norm and framework; (ii) clarify its expectations with the auditors, as much as needed; (iii) ensure that its requests are specific and clearly defined and that they describe the standards against which the entity's performance can be measured, so that the auditor can report whether or not they have been achieved; (iv) reach some understanding with the external auditors regarding the concept of materiality, as needed; (v) revisit the frequency of the requests made to auditors and consider the adoption of rotation plans or different frequencies (higher and lower) of current requests and agree on a work program over a certain period of time; (vi) ensure high standards of bank auditing (independence in appearance and fact, proper licensing and good standing, relevant professional experience and competence, subject to quality assurance programs, compliance with ethical requirements); and (vii) consider the hiring of independent audit firms to make an assessment of the quality of a specific bank audit, as needed.

\section{B. Sectoral Findings}

35. This section summarizes the findings in the assessment of standards and codes for banking and in the review of the regulation and supervision of the CIS and insurance sectors. It also includes an initial review of AML/CFT practices, based on information provided by the authorities and discussions with UPB and INAF senior staff and external auditors. The mission had access to the preliminary results of the mutual evaluation conducted by MONEYVAL in October 2005, but a ROSC on compliance with AML/CFT standards will only be prepared once the final results of this evaluation are issued, in mid-2007, according to the authorities' expectations.

\section{Banking}

36. The assessment found a high level of compliance with the BCP and a notable improvement with respect to the 2002 assessment. Andorra is compliant with 21 principles

and largely compliant with 8 principles. The only principle that is still materially noncompliant is Principle 25, on the supervision of foreign bank establishments. Under INAF's charter Andorra is now able to sign agreements for cooperation and information exchange with foreign supervisors, but INAF's efforts in this regard have not yet been effective. Restrictions on the access of supervisors of foreign banks to nominative information of the banks' customers prevented an agreement with the BE. Looking forward, the INAF should step up its efforts to sign agreements with foreign supervisors, to develop its 
on-site supervisory capacities and to improve the effectiveness of the oversight delegated to external auditors. Additionally, it is advisable to empower the INAF to make the final decisions regarding granting and revoking bank licenses and issuing all types of sanctions; and to improve disclosure of the INAF's activities and financial statements (details in Appendix III).

\section{Collective investment schemes}

37. There are at present no regulations specific to the CIS sector. However, several statutes of general application to the financial system apply. In carrying out its mandate in that context, INAF issued several mandatory Directives, which at present govern CIS supervision, pending elaboration and promulgation of a CIS specific statute. A new CIS regulation law has been drafted and is, reportedly, among the government's legislative priorities. It would comprehensively and specifically substantiate the CIS regulatory and supervisory regimes, and address CIS creation, modification and termination; fiduciary and prudential obligations; accounting, auditing, regulatory reporting; market disclosure and conduct of business procedures and practices. It might need enhancement as regards CIS specific bases for asset valuation, pricing and redemption of CIS units, as well as disclosure to retail investors.

\section{Insurance}

38. The regulation and supervision of insurance companies is insufficient, and in view of its increasing importance, efforts to strengthen them should be stepped up. Currently supervision is carried out by the MF, but there is no area solely dedicated to insurance supervision in the MF; these tasks are carried out by the tax department within the MF. Supervision consists mainly of analyzing audited financial statements. There are no suitable regulatory arrangements. Prudential and conduct of business regulation are limited. There are no international cooperation provisions or practices. It is essential that the government implement in the short run the provision included in INAF's charter, regarding the transfer to INAF of the responsibility for supervising this sector, increase insurance oversight capacity and give priority in their legislative program to a new insurance regulation law.

\section{Anti-Money Laundering/Combating the Financing of Terrorism (preliminary analysis, pending the issuance of the final MONEYVAL report)}

39. Andorra's legal framework in anti-money laundering and combating the financing of terrorism is largely based on the Law on International Criminal Cooperation and Combating Laundering of Money or Valuables Resulting from International Crime issued in 2000. The law provides for formalized international mutual cooperation on criminal matters; creates and empowers the UPB with exclusive jurisdiction over money laundering investigations and supervision; provides comprehensive costumer due diligence and record keeping, and sets 
detailed suspicious transaction reporting requirements. The law may be supplemented by technical communications issued by the UPB. The INAF has been divested of a role in this area.

40. During 2005, a team of the Council of Europe's MONEYVAL visited Andorra. The mission had access to the preliminary results of the third visit conducted by the team from October 17-21, 2005, and the assessment was generally favorable, finding that Andorra had continued to make progress in the area of AML/CFT; but it also pointed out to several aspects in need of further improvements.

41. The UPB has conducted on-site inspections in banks, nonbank financial institutions and insurance companies. Since end-2002, the UPB has requested external auditors to report on a range of issues that include, inter-alia, procedures and systems in place in banks to assess fit-and-proper of key staff; internal control systems and procedures; suspicious transactions reported by employees to bank management; training given to employees on money laundering and financing of terrorism; opinion on the overall efficiency of procedures aimed to prevent and detect money laundering activities.

42. Legislation that should modify the 2000 law has been drafted and is pending Parliament approval. This legislation would adapt Andorra's AML/CFT regime to the revised Financial Action Task Force Recommendations and address some issues raised by MONEYVAL by (i) specifically addressing activities related to financing of terrorism; (ii) expanding the definition of supervised entities and individuals; (iii) making UPB Comunicados Tecnicos binding for supervised entities; and (iv) better identifying an entity's customers and empowering the UPB to impose sanctions, except those considered very grave that should still rest on the central government.

43. The UPB does not consider that numbered accounts are an obstacle to the authorities considering that banks comply with the know-your-customer requirements. It charges external auditors with specific due diligence requests on these accounts as well as on other areas of concern. Regarding Politically Exposed Persons, the draft legislation does not contain any particular obligation or mention, however the comunicados tecnicos of UPB and the Ethical Code issued by INAF refer to these.

\section{Cross-Border Cooperation and Information Exchange}

44. The laws governing financial institutions contain provisions to maintain the secrecy and confidentiality of information obtained by the supervisors, as well as to provide gateways for the exchange of information. Revealing confidential information is a violation of the professional secret and, as such, is penalized by the law (Article 191 of the Penal Code).

45. Both INAF and UPB are empowered to enter into cooperation agreements with foreign authorities. 
46. Since 2002, the UPB is allowed to enter into cooperation agreements on criminal matters and AML/CFT with foreign authorities. Since then the UPB has signed agreements with the corresponding AML authorities in Bahamas, Belgium, Dutch Antilles, France, Luxembourg, Monaco, Peru, Poland, Portugal, Spain, and Thailand. The UPB has cooperated with foreign authorities to detect and prosecute criminal activities and freeze accounts in various occasions. The UPB is a member of the Egmont Group since 2002, and has shared information and cooperated closely with other Egmont group members.

47. Under its charter (Article 9), the INAF can establish relations and cooperation agreements with foreign central banks and supervisory authorities and with other national and international organizations on matters related to the financial sector. INAF is yet to sign cooperation agreements with foreign supervisors, but is in conversations to do so with the authorities of Bahamas. Earlier conversations to sign a cooperation agreement with the BE were not successful. Restrictions on the ability of the foreign supervisor to have full access of nominative information on their assets and to conduct on-site examinations on affiliates of foreign banks without prior notice to INAF were an obstacle to this agreement. The INAF has indicated that it would be willing to facilitate nominative information of large exposures and that it would welcome the opportunity to conduct joint on-site inspections with foreign supervisors. While these are important steps, it is recommended to empower INAF to share with the home country supervisor all information about the local operations of the foreign banks, necessary to conduct an effective supervision of these banks, provided its confidentiality is protected. It must be noted that the decreasing participation of Spanish banks in the Andorran banking system, which will be down to some 4 percent of assets and deposits and 2 percent of capital by end-2006, has lowered the authorities' sense of urgency with regards to signing this cooperation agreement.

48. While there are no international cooperation provisions in the insurance sector the MF can communicate with foreign supervisors if required. However, its ability to exchange useful information has been constrained by the limited scope of the information it collects and reviews under current statute. 


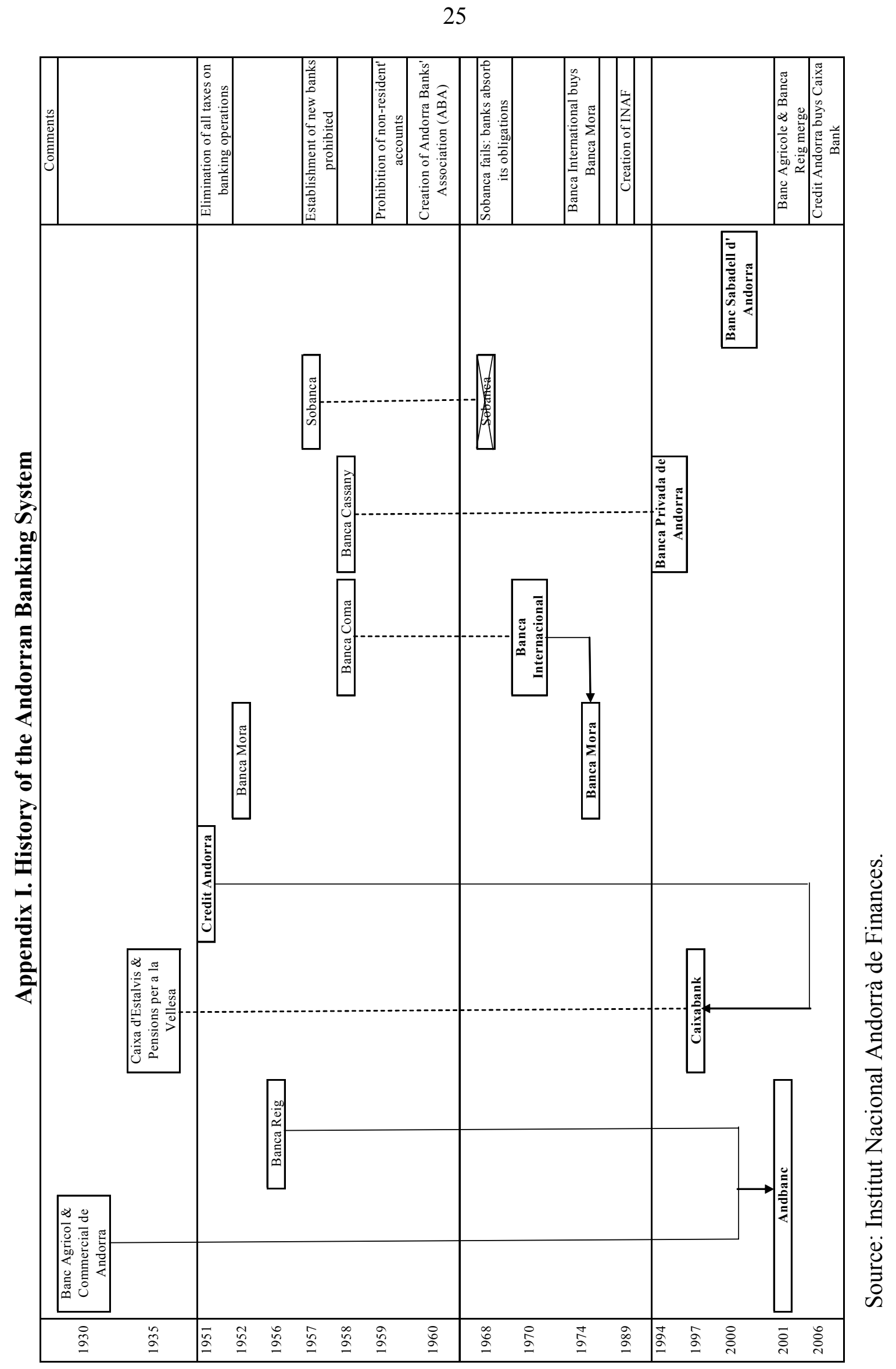




\section{Appendix II. Follow up of Implementation of Recommendations Contained in the 2002 Module 2 Report}

\begin{tabular}{|c|c|}
\hline Recommendation & Action Taken \\
\hline \multicolumn{2}{|c|}{ Bank Regulation and Supervision } \\
\hline $\begin{array}{l}\text { BCP 1.1. Clear responsibilities and objectives of the supervisor } \\
\text { The INAF should have authority to determine applicable regulation } \\
\text { and supervisory policies within the constraints of the law. These } \\
\text { should include the ability to contract and direct the work of external } \\
\text { auditor's complementary onsite work; conduct onsite inspections } \\
\text { when necessary, and budget independence for staffing and resource } \\
\text { requirements without seeking prior approval. The mission also } \\
\text { encourages that the authority to approve licensing decisions (within } \\
\text { the constraints of the law) also be included among the powers of } \\
\text { INAF. }\end{array}$ & $\begin{array}{l}\text { INAF's charter redefines its functions and grants it more } \\
\text { independence. The INAF can issue regulations, apply } \\
\text { supervisory policy, conduct on-site inspections without } \\
\text { prior authorization of the Finance Minister and hire } \\
\text { external auditors to independently verify banks' } \\
\text { information. I also have budget independence and } \\
\text { licensing decision power. INAF has issued Communication } \\
157 / 03 \text { in December } 2003 \text {, introducing requirements for } \\
\text { the external auditors to include in their mandatory } \\
\text { complementary audit report }\end{array}$ \\
\hline $\begin{array}{l}\text { BCP 1.2. Operational independence and adequate resources } \\
\text { The INAF develop a capacity to carry out some onsite inspection } \\
\text { activity to gain a deeper understanding of the activities of the banks } \\
\text { and other financial institutions that it supervises. Caution is } \\
\text { warranted against adding functions to INAF that are not compatible } \\
\text { with its financial sector supervisory role. The supervision of } \\
\text { insurance activities should be included among INAF's } \\
\text { responsibilities. }\end{array}$ & $\begin{array}{l}\text { Under its charter, the INAF has budget independence for } \\
\text { staffing and resource requirements. Within the last year the } \\
\text { INAF has increased its staff from eight to twelve. }\end{array}$ \\
\hline $\begin{array}{l}\text { BCP 1.4. Suitable legal framework } \\
\text { Remove the prior approval encumbrances that could affect the } \\
\text { ability of INAF to act promptly as may be required in an } \\
\text { enforcement action. }\end{array}$ & $\begin{array}{l}\text { The INAF has the authority to act promptly as may be } \\
\text { required in an enforcement action and can dismiss } \\
\text { temporarily members of management and board of } \\
\text { directors, and appoint a temporary management in a bank. } \\
\text { However, the authority to issue an orderly resolution of a } \\
\text { problem bank that includes the removal of a bank's license } \\
\text { is not vested in the INAF. }\end{array}$ \\
\hline $\begin{array}{l}\text { BCP 3. Licensing Criteria } \\
\text { Best practice would ensure a more formalized requirement that } \\
\text { INAF provide its formal consent to all applications. }\end{array}$ & $\begin{array}{l}\text { The government has the final authority to approve or deny } \\
\text { permits for the issuance of new banking licenses. The } \\
\text { government has so far always rendered its decisions based } \\
\text { on the technical recommendations of the INAF. }\end{array}$ \\
\hline $\begin{array}{l}\text { BCP 7. Credit policies } \\
\text { INAF should foster a strong credit culture by promoting sound credit } \\
\text { policies through a core verification requirement in the } \\
\text { complementary audit or a periodic, systematic review by INAF staff. }\end{array}$ & $\begin{array}{l}\text { The INAF has issued Communication } 157 / 03 \text { in } \\
\text { December 2003, introducing requirements for the external } \\
\text { auditors to include in the complementary audit report } \\
\text { information covering verification of the credit policies } \\
\text { issued by banks. }\end{array}$ \\
\hline $\begin{array}{l}\text { BCP 8. Loan Evaluation and Provisioning } \\
\text { Request external auditors to render judgments over loan loss } \\
\text { provisioning. }\end{array}$ & $\begin{array}{l}\text { INAF has issued Communication } 157 / 03 \text { in } \\
\text { December 2003, introducing requirements for the external } \\
\text { auditors to include in the complementary audit report a } \\
\text { detailed credit risk analysis, including loan loss } \\
\text { provisioning. }\end{array}$ \\
\hline
\end{tabular}




\begin{tabular}{|l|}
\hline \multicolumn{1}{|c|}{ Recommendation } \\
\hline BCP 9. Large Exposure Limits \\
INAF should request that external auditors render a conclusion on \\
whether or not the financial institution has established adequate \\
management information systems to ensure ongoing compliance \\
with concentration limits. This requirement should be explicit in the \\
complementary audit scope.
\end{tabular}

\section{BCP 13. Other Risks}

Ensure that external auditors evaluate policies and practices across functional areas to reach conclusions on the level of adherence to policies and procedures throughout the institution and the extent of oversight, support and direction provided by Boards of Directors. Expand the frequency and depth of discussions with Boards of Directors regarding the strategic direction and the level of risk tolerance of their institutions to better evaluate the adequacy of risk management programs in light of conclusions reached through external auditor's reports.

\section{BCP 14. Internal Control and Audit}

Ensure that complementary audits incorporate reviews of internal controls, specifically to cover growing, off balance sheet activities such as custody services. It is important to assure that bank activities are properly segregated from the banks' own operations and that adequate controls are in place to protect against possible fraud or misappropriation.

Ensure that external auditors test and reach conclusions regarding the independence of the internal audit function and the degree of importance the Board of Directors provides the audit function.

\section{Action Taken}

The INAF has issued in December 2003, Communication $157 / 03$ specifying the scope of the information to be included in the Complementary Report submitted in conjunction with the Annual Financial Statement Report.

This Communication includes in Section 6 explicit requirements for the external auditors to assess the information systems covering concentration limits.

There is no evidence that credits to members of the Board, insiders and related interests are approved by the bank's Board of Directors.

According to the Communication 163/05 issued in February 2006, all staff, including members of the Board of Directors should avoid conflicts of interest of any type. There is no clear evidence that credits to insiders and related interests should not be granted at preferential rates.

The INAF has supplied additional guidance to the external auditors for the preparation of the complementary annual reports. Communication 157/03 of December 2003, instructs the external auditors to include in the conclusions of the complementary report an overall assessment of the situation of the bank and include a global evaluation of the operational risk management. INAF indicates that there are very frequent personal and business contacts between the management of the INAF and members of the Board of Directors of the banks to discuss matters covering their bank strategic direction and the level of risk tolerance of their institution.

Communication 157/03 of December 2003, instructs the external auditors to review off balance sheet activities and, inter alia, make an evaluation of internal control processes. However, it does not require a conclusion regarding the independence of the internal audit function and the degree of importance the Board of Directors provides the audit function. 


\begin{tabular}{|l|l|}
\hline \multicolumn{1}{|c|}{ Recommendation } & \multicolumn{1}{c|}{ Action Taken } \\
\hline $\begin{array}{l}\text { BCP 15. Money Laundering } \\
\text { There should be a formal mechanism for ensuring that necessary } \\
\text { information is passed between UPB and INAF. }\end{array}$ & $\begin{array}{l}\text { Monthly meetings of the Director of the UPB, the INAF, } \\
\text { the Ministers of Finance and Interior are held to discuss } \\
\text { anti money laundering measures. In addition, Article } 53 \text { of } \\
\text { the Law of International Penal Cooperation and the Fight } \\
\text { Against Money Laundering requires the exchange of } \\
\text { information in this area. }\end{array}$ \\
\hline
\end{tabular}

\section{BCP 16. Onsite and Offsite Supervision}

A more in-depth and integrated analysis should be done on the banks and the system. The assessments should arrive at integrated conclusions over the condition of the institutions, their likely trajectory in the near term, and the principal supervisory concerns to be addressed through further off-site analysis or external audit follow-up. The mission further recommends that INAF develop a capacity to conduct onsite inspections.
The assessment of complementary audit report does not include an overall opinion on the financial condition of the institutions. However, the supervisors arrive at integrated conclusions after a follow up with the auditors and bank management Additionally, INAF is developing its capacity to conduct onsite inspections and plans to commence the onsite inspections in late 2007, while continuing to use, for a time, the services of the external auditors. Concurrent with this process the INAF will carry on an intensive training program and plans to hire additional supervisors.

INAF has expanded significantly the scope of the complementary audit and has instructed banks to comply with the five year rotation program of external auditors. In addition, the INAF has formalized the exchange process of information with the banks and the external auditors by issuing Communication 126/01 that establishes an annual meeting with the member of General Management responsible for internal control and the partner of the audit firm responsible for the preparation of the complementary audits.

Communication 157/03, requires the external auditors to furnish details in the Complementary report on each one of the subsidiaries of a bank including, among other, the method of consolidation, the percentage of participation and financial details of the subsidiaries. Risks emanating from non-banking products or activities are identified in the Complimentary Report. INAF's charter includes a provision to incorporate the insurance companies under INAF's direct supervision.

The INAF has made attempts to enter into MOU's with the Spanish and French bank supervisors. However, the efforts have not been successful.

Within the last year, the INAF has increased its staff from eight to twelve and plans to start on-site exams in late 2007. building of a credible capacity to carry out onsite inspections. The strengthened capacity within INAF would allow the home country supervisor to have greater level of assurance regarding the adequacy of supervision of subsidiaries in Andorra. 


\begin{tabular}{|c|c|}
\hline Recommendation & Action Taken \\
\hline \multicolumn{2}{|c|}{ Insurance regulation and supervision } \\
\hline $\begin{array}{l}\text { Legal framework } \\
\text { Revision of the legal framework, inline with EU practices }\end{array}$ & $\begin{array}{l}\text { A draft law has been prepared, but is yet to be submitted to } \\
\text { the General Council. }\end{array}$ \\
\hline $\begin{array}{l}\text { Independent supervisory body } \\
\text { Transfer of insurance oversight to INAF, with sufficient resources }\end{array}$ & $\begin{array}{l}\text { INAF's charter mandates that regulations be issued to } \\
\text { integrate the supervision of insurance companies into the } \\
\text { INAF. But these regulations have not been issued. }\end{array}$ \\
\hline $\begin{array}{l}\text { Financial and accounting standards } \\
\text { Adoption of uniform financial and accounting standards for the } \\
\text { insurance industry. It is recommended that EU standards be adopted. }\end{array}$ & $\begin{array}{l}\text { An accounting draft law is being studied by the } \\
\text { government, with the aim to adopt and implement IFRS in } \\
\text { all Andorran companies. }\end{array}$ \\
\hline \multicolumn{2}{|c|}{ AML/CFT - Legal and institutional framework } \\
\hline $\begin{array}{l}\text { Organizational and Administrative Considerations } \\
\text { UPB resources should be evaluated for possible adjustment. Provide } \\
\text { a formal mechanism for communication between UPB and INAF. } \\
\text { Review suspicious transaction report mechanism and guidance after } \\
\text { a period of implementation. }\end{array}$ & $\begin{array}{l}\text { UPB counts with } 2 \text { financial members appointed by the } \\
\text { MF, } 2 \text { police staff appointed by the Ministry of Interior, a } \\
\text { Judge from the High Council of Justice and as many } \\
\text { administrative staff as needed. The Director is appointed } \\
\text { by both Ministers. Since } 2005 \text {, monthly meetings are } \\
\text { informally held with the INAF to discuss common areas of } \\
\text { interest. }\end{array}$ \\
\hline $\begin{array}{l}\text { UPB Internal Rules } \\
\text { Waiver should be required authorizing UPB to meet directly with } \\
\text { external auditors. Require updates to UPB of any change in AML } \\
\text { regime between audits, including submission of updated internal } \\
\text { procedures. Formalize UPB's procedure to follow up on the external } \\
\text { audits. Permit UPB to order additional external audits as necessary. } \\
\text { Consider auditing UPB's operations. }\end{array}$ & $\begin{array}{l}\text { UPB has the ability to meet directly with external auditors } \\
\text { as much as deemed needed, usually, in the presence of the } \\
\text { entity's compliance officer. UPB has the authority to } \\
\text { inquire about changes of auditors; require that auditors } \\
\text { follow up on recommendations given in a previous audit } \\
\text { report or that auditors perform special audits/reviews. } \\
\text { UPB's operations are reported to the Ministry of Interior } \\
\text { and audited by a Supreme Tribunal (Tribunal de Comptes). }\end{array}$ \\
\hline $\begin{array}{l}\text { External Audits } \\
\text { Ensure submission of unedited auditor's reports to UPB. Consider } \\
\text { possible preparatory meetings between UPB and external auditors. } \\
\text { Evaluate the criteria for external audit after the first reports are } \\
\text { received and consider modifications, including specific sample } \\
\text { testing for numbered accounts. }\end{array}$ & $\begin{array}{l}\text { UPB understands that it gets unedited auditor's reports } \\
\text { from banks. Preparatory meetings with external auditors, } \\
\text { follow-up meetings or meetings for making special } \\
\text { requests to auditors are conducted as deemed needed. }\end{array}$ \\
\hline $\begin{array}{l}\text { Legal } \\
\text { Complete assessment of compliance with international conventions } \\
\text { and complete changes to the Penal Code as necessary. Assess the } \\
\text { measures to protect bona fide third parties in confiscation } \\
\text { proceedings. } \\
\text { Assess if it is necessary to permit judges to void contracts that are } \\
\text { money laundering related. } \\
\text { Protect financial intelligence and internal operations of UPB. } \\
\text { Analyze the scope of constitutional protection afforded to } \\
\text { government employees and advise UPB and the judiciary on the } \\
\text { scope. }\end{array}$ & $\begin{array}{l}\text { Changes to the Penal Code were passed by Parliament in } \\
\text { February } 2005 \text {. Key changes included increasing the list of } \\
\text { offences/crimes that qualify as money-laundering and } \\
\text { financing for terrorism activities (a total new } 46 \text { such } \\
\text { crimes/offences were included) as well as increasing the } \\
\text { severity of sanctions (starting from a minimum } 3 \text { years of } \\
\text { prison) for violations of the new rules. Legislation is } \\
\text { pending to introduce financing of terrorism activities in } \\
\text { current law and make the UPB's Comunicados binding for } \\
\text { supervised entities } \\
\text { Judges may void contracts that are money laundering } \\
\text { related if deemed necessary. } \\
\text { Internal operations of UPB are deemed by the unit as }\end{array}$ \\
\hline
\end{tabular}




\begin{tabular}{|c|c|}
\hline Recommendation & Action Taken \\
\hline & $\begin{array}{l}\text { protected. Officers enjoy legal protection and the central } \\
\text { government is responsible for paying all claims and suits } \\
\text { when resulting from the faithful exercise of their } \\
\text { supervisory work. }\end{array}$ \\
\hline \multicolumn{2}{|c|}{ AML/CFT in the banking sector } \\
\hline $\begin{array}{l}\text { External Audits } \\
\text { UPB should request external auditors to assess fit-and proper test } \\
\text { procedures of banks. }\end{array}$ & $\begin{array}{l}\text { UPB requests external auditors to inform what are the } \\
\text { procedures and systems that banks have in place to assess } \\
\text { fit-and-proper of their key staff. Rules for fit-and-proper of } \\
\text { directors are specified in a separate law (lack of criminal } \\
\text { records, pertinent professional and work history, etc.). }\end{array}$ \\
\hline $\begin{array}{l}\text { Potential Comunicat Tecnic } \\
\text { Respond to requests for additional guidance on how banks should } \\
\text { handle customers whose transactions have been blocked. }\end{array}$ & $\begin{array}{l}\text { Where transactions/accounts have been blocked, UPB } \\
\text { provides guidance to banks upon request. }\end{array}$ \\
\hline $\begin{array}{l}\text { Legal } \\
\text { Subject all employees of banks to fit-and-proper requirements and } \\
\text { require banks to screen new employees for criminal records. }\end{array}$ & $\begin{array}{l}\text { Banks have procedures to screen new employees for } \\
\text { criminal records and auditors are required to inform UPB } \\
\text { about such procedures. Fit-and-proper requirements are } \\
\text { mandatory for key staff. }\end{array}$ \\
\hline
\end{tabular}




\section{Appendix III. Reports on the Observance of Standards and Codes}

\section{Summary Assessment of Compliance with the Basel Core Principles for Effective Banking Supervision}

\section{General}

49. The assessment of Observance with the Basel Core Principles for Effective Banking Supervision is based on the Core Principles Methodology (Basel Committee on Banking Supervision, October 1999). The assessors benefited from the full cooperation of the authorities and received all necessary information. Their cooperation is gratefully acknowledged.

50. The assessment is based on the following sources: (i) the legal and regulatory framework, contained mainly in the four laws applicable to all financial institutions and the directives issued by the INAF; (ii) the self-assessment of compliance with the Core Principles as of August 2006 prepared by the INAF; (iii) the 2002 BCP assessment conducted by the IMF in the context of the assessment of Andorra's financial system; (iv) external audit reports, including a sample of Complementary Reports ${ }^{15}$; (v) various reports prepared by INAF; and (vi) extensive discussions with the senior and supervisory staff of the INAF, as well as meetings with bankers, external auditors and other market participants.

\section{Preconditions for effective banking supervision}

51. The preconditions for effective banking supervision in Andorra are generally in place. There are no identifiable macroeconomic vulnerabilities and risks that could have implications for the structure and financial performance of the banking industry or the effectiveness of prudential safeguards or the stability of the financial system. The public infrastructure provides for an environment that fosters the honoring and enforcement of financial contracts.

52. The small size of the local economy facilitates assessment of credit risk in the loan portfolio, and the absence of a credit bureau does not seem to have affected loan evaluation, as evidenced by the low level of past due loans ( about 0.2 percent of total loans in 2005). Nevertheless, the authorities have mentioned their intentions of working with the industry toward the implementation of a credit bureau. While there is no public registry in Andorra,

\footnotetext{
${ }^{15}$ Complementary Reports (Informes Complementaris) are prepared by external auditors following the requirements issued by INAF, and they cover assessments of a broad range of issues including internal controls, risks management and compliance with key prudential requirements.
} 
the notaries perform the task of recording liens on real estate and other property suitable for collateral. The court system is effective and efficient, and the execution of collateral reportedly takes less than one year.

53. The flow of information on banking institutions to market participants is considered adequate, albeit disclosure of higher frequency data would be desirable. While there is no publicly available official information on the financial strength and performance of the banking industry, banks publish their annual audited financial statements both electronically and in printed form, and the ABA publishes an annual report, which contains a section on the financial environment including financial indicators of individual banks and the banking system.

54. There are no official accounting standards in Andorra, except the chart of accounts of the financial system issued by the INAF in 1999. These standards, inspired by the BE accounting standards of that time, are generally adequate but an updating is warranted in the context of IFRS. The authorities are preparing a draft accounting law by which all Andorran companies would adopt standards consistent with IFRS, with implementation estimated by 2008 . The INAF is in favor of all banks adopting IFRS. The aim would be to adopt and implement IFRS in all banks as soon as draft legislation is passed by the CG and to adapt prudential regulations as needed to narrow the accounting choices available for banks.

55. Andorra has a legal and regulatory framework with flexible power for the government to effect a resolution of problem banks. Nevertheless, an immediate challenge for the authorities is to carry out modifications to the current regulation to empower the INAF as the only authority in Andorra to undertake all types of remedial actions, including the revocation of a bank's license.

56. There is no deposit insurance in place nor is there a lender of last resort. However, all banks are required to participate in a guarantee fund. The funds are deposited in banks, and would be available to facilitate resolution of a troubled financial institution. Whether and how the fund could be used in the event that there were a problem with one of Andorra's banks has not been defined. In the medium term, the authorities foresee the implementation of a fully defined deposit and investments insurance fund.

\section{Main findings}

57. Andorra has a high level of compliance with the BCP. Andorra is compliant with 21 principles and largely compliant with 8 principles. The only principle that is still materially noncompliant is principle 25 , on the supervision of foreign bank establishments. The following summarizes the main findings of the detailed assessment of compliance with the BCP: 


\section{Objectives, Autonomy, Powers, and Resources (CP 1)}

58. INAF is the Authority of the Andorran financial system and promotes and sees to the proper working and stability of the financial system. Under its charter, INAF has operational and budgetary independence and the authority to issue regulations that provide a framework of prudential standards that banks must meet. It has disciplinary and sanctioning powers over the institutions integrated in the financial system, with the exception of the most serious sanctions, which are issued by the government, ${ }^{16}$ with prior opinion of INAF. Similarly, the government has the final power to authorize and revoke banking licenses, with prior opinion of INAF. There is no evidence of government interference and, reportedly, the government has always followed INAF's advise. INAF is funded by the revenues derived from investment income of a fund provided for by the Andorran government and by additional government budget resources, if needed. It is recommended that the powers to impose all sanctions, and to authorize and revoke a banking license, be granted to the INAF solely.

59. The supervisory agency and its staff have good credibility based on their professionalism and integrity. The legal protection of INAF employees is the same as that available to all officials, civil servants, and agents under employ of the government. Generally, the administration is held liable for the actions of its employees, including INAF employees, when they are acting in an official capacity.

\section{Licensing and Structure (CPs 2-5)}

60. The term bank is clearly defined in the law, along with the operations and services that may be provided by banking institutions supervised by the INAF. The 1998 Law regulating the creation of new banking institutions establishes the criteria and the requirements for new banking licenses. The final decision to approve or withdraw licenses is taken by the government, based on the analysis and recommendations of the INAF. From a supervisory point of view, being that INAF is the institution that will supervise the new bank, it would be more appropriate if the final decision in the licensing process is made by the supervisory authority instead of the Minister of Finance.

61. Regulation has a clear definition of qualified ownership and requires the INAF approval in any change in ownership of a bank to be valid. The INAF has the power to obtain information on individuals and legal entities that purchase stock of a banking institution at any amount. There are no bearer shares. Article 18 of the Bank Administration Law gives the INAF the powers to deny authorization to become a shareholder to any individual or to the shareholders of any legal entity. Regulation sets the criteria and various types of limits on investments that banking institutions may carry out in relation to their own capital and in relation to the capital of the nonfinancial institutions.

\footnotetext{
${ }^{16}$ The government is comprised of the Cap de Govern and all the ministers.
} 


\section{Prudential Regulations and Requirements (CPs 6-15)}

62. Prudential regulation and requirements are considered adequate and the INAF is legally empowered to enforce them. Capital requirements in Andorra are consistent with the Basel Capital Accord. A minimum capital ratio of 10 percent is required on a solo and a consolidated basis, and there are capital requirements to cover market risks.

63. The INAF has the authority to assess credit granting and investment policies and procedures. The Chart of Accounts states that banks subject to credit risk must charge the profit and loss account with the necessary general or specific loan loss provisions. It also defines the classification of loans and provisioning in four categories. There is quarterly reporting on the quality and composition of the loan and investment portfolios and information of collaterals for off-site credit analysis. The definition of "related group" is included in the Chart of Accounts. Banks must avoid risk concentration exposures and there is a limit of 15 percent of bank capital over any kind of exposure with members of the Board of Directors. Banks are required to report quarterly on concentration limits and related party exposures on a consolidated basis. Banks must comply with the principles and guidelines set in the Ethic Code, which include a requirement to issue internal procedures to be followed by bank staff and representatives when carrying out their own operations. However, there is no explicit mention that bank's credits to insiders and related interests should not be granted at preferential rates, and that these operations require Board approval. INAF relies on the external auditors for on-site verification, through an annual complementary report.

64. INAF has issued requirements for the management of country, transfer, market, liquidity, interest rate and foreign exchange risks. There are reporting requirements that allow INAF to conduct an off-site analysis of these risks, but INAF relies on external auditors for the on-site verification. In the case of operational risk, external auditors are required to evaluate banks' policies and practices and report to INAF in the annual complementary report. The external auditors are required to assess the adequacy of the internal audit function and are responsible for reviewing that policies and procedures established by management of the bank are complied with, and whether the existing policies, practices and controls are sufficient and appropriate for the bank's business.

\section{Methods of Ongoing Supervision (CPs16-20)}

65. INAF's supervision of the financial sector consists of off-site compilation and analysis of quarterly data submitted by financial institutions in accordance with the Chart of Accounts. Information is submitted on a solo and a consolidated basis. INAF has not conducted its own on-site examinations since its creation in 1989, and has relied on the onsite work of external auditors for the validation of information, compliance with prudential requirements and assessment of internal controls and risk management. The supervisors conduct a tripartite annual meeting with each individual bank and the bank's external 
auditors to discuss, among other aspects, the developments in the financial institution, the extent of its risks, its compliance with the laws and regulations and the scope of complementary audits. In addition, INAF's officers and supervisory staff have formal and informal communications with bank managers, directors and bank association leaders during the year to discuss the condition and risks affecting their institution.

66. INAF's staff is very lean (12 staff members) and management should take steps to gradually increase the number of its supervisors in order to be able to conduct on-site inspections of the financial institutions with its own supervisory staff, thus placing less reliance on the external audit firms to conduct complementary audits on its behalf. In the meantime, to ensure that external auditors provide an effective support for bank supervision, INAF needs to clarify the requirements for the complementary reports.

\section{Information Requirements (CP 21)}

67. Accounting standards in Andorra are satisfactory though they may require updating in some aspects such as the accounting for derivatives which are currently reported as offbalance sheet items. According to the MF, proposed legislation to be adopted in the near future would mandate the adoption of international accounting standards.

\section{Formal Powers of Supervisors (CP 22)}

68. The INAF has a wide range of powers to bring about corrective actions for noncompliance with laws and regulation. It has the authority to impose sanctions upon banks in accordance with the seriousness of the transgression committed. These sanctions include fines applied to the bank or to the staff responsible; suspension, dismissal or disqualification of the bank's board members or staff responsible; prohibition from distributing dividends; among other type of disciplinary measures. The sanctions in the category of "very severe" related to the compliance of solvency, liquidity, concentration risk, among other prudential regulation, that currently are within the authority of the government, should be within the jurisdiction of the INAF.

\section{Cross-Border Banking (CPs 23-25)}

69. The cross border operations of Andorran banks are few (Bahamas, Panama, and Uruguay) and represent a very small share of the business of the banking groups.

Nevertheless, the INAF ensures the adequacy of the bank's overall condition through the analysis of quarterly consolidated financial reports provided by banks, which include financial information of subsidiaries; and through the evaluation made by the external auditors on this respect and on risk management. Banks are required to inform the INAF before the establishment abroad of foreign branches and subsidiaries, and INAF has the authority to deny the constitution of the foreign branches or subsidiaries of the local bank INAF has the authority to establish relations and cooperation agreements with foreign supervisory authorities, but has not yet signed any. Efforts to agree on an MOU with the BE 
were not successful. Restrictions on the ability of the foreign supervisor to conduct unannounced on-site examinations on affiliates of foreign banks and have full access of nominative information on their assets were an obstacle to this agreement. The INAF has indicated that it is willing to facilitate nominative information of large exposures and that it would welcome the opportunity to conduct joint on-site inspections with foreign supervisors. While these are important steps, it is recommended to empower INAF to share with the home country supervisor all information about the local operations of the foreign banks, necessary to conduct an effective supervision of these banks, provided its confidentiality is protected...

\section{Table 6. Andorra: Recommended Action Plan to Improve Compliance with the Basel Core Principles}

\begin{tabular}{|c|c|}
\hline Reference Principle & Recommended Action \\
\hline CP1 (2) Independence & $\begin{array}{l}\text { Publish a periodic review of INAF's performance against its responsibilities and } \\
\text { objectives. }\end{array}$ \\
\hline CP1 (3) Legal Framework & $\begin{array}{l}\text { Amend INAF's charter to empower INAF to issue licenses and conduct an } \\
\text { orderly resolution of a problem bank. INAF should introduce a legal supervisory } \\
\text { framework that will cover insurance companies. }\end{array}$ \\
\hline CP1 (4) Enforcement Powers & $\begin{array}{l}\text { Amend INAF's charter to empower INAF to undertake all types of remedial } \\
\text { actions, including the very serious sanctions and the revocation of a bank } \\
\text { license. }\end{array}$ \\
\hline CP 10 Connected Lending & $\begin{array}{l}\text { The INAF must ensure that credits to insiders and related interests should not be } \\
\text { granted at preferential rates and that transactions to insiders, such as the credits } \\
\text { to the members of the bank's Board of Directors, should be required to be } \\
\text { approved by the Board. }\end{array}$ \\
\hline CP 14 Internal Control and Audit & $\begin{array}{l}\text { Members of the Board of Directors of financial institutions should participate in } \\
\text { the yearly meetings with auditors and the INAF. }\end{array}$ \\
\hline CP16 On-site and Off-site supervision & $\begin{array}{l}\text { INAF should gradually increase the number of its supervisors in order to be able } \\
\text { to place less reliance on the external audit firms that conduct complementary } \\
\text { audits on its behalf. } \\
\text { INAF should have a system specialist on its staff to support the on-site and off- } \\
\text { site areas. }\end{array}$ \\
\hline CP 20 Consolidated Supervision & $\begin{array}{l}\text { The activities of insurance companies should come under the supervision of the } \\
\text { INAF. }\end{array}$ \\
\hline CP 22 Remedial Measures & $\begin{array}{l}\text { Amend INAF's charter to empower INAF to undertake all types of remedial } \\
\text { actions, including the revocation of a financial institution's license. }\end{array}$ \\
\hline CP 24 Host Country Supervision & $\begin{array}{l}\text { The INAF should enter into an MOU with the Banking supervisory authority of } \\
\text { Uruguay and set the scope of information sharing, in order to have the necessary } \\
\text { information for an adequate supervision of foreign subsidiaries. }\end{array}$ \\
\hline $\begin{array}{l}\text { CP 25. Supervision Over Foreign Banks' } \\
\text { Establishments }\end{array}$ & $\begin{array}{l}\text { The INAF should intensify its efforts to enter into a formal agreement with the } \\
\text { banking authorities of Spain that will allow full compliance of Andorra as a host } \\
\text { country supervisor. } \\
\text { The INAF should share with the home country supervisor information about the } \\
\text { local operations of the foreign banks, provided its confidentiality is protected. }\end{array}$ \\
\hline
\end{tabular}




\section{Authorities' response}

70. The Andorran authorities welcome that the assessment recognises that their supervisory system is broadly sound and that efforts have been made to address several recommendations of the 2002 IMF mission. They also indicated that they wish to continue improving financial sector supervision, as evidenced by the several draft laws and regulations that are in the process of being approved at the time of the assessment. The Andorran authorities agreed with most of the assessment and recommendations. However, they have some observations on the assessment of CPs 1, 10, 14, 16 and 20.

71. Regarding CP 1 the authorities highlighted that the current legal framework has demonstrated its efficacy throughout the years due to the good cooperation between the MF and the INAF. They also stressed that the government always takes into account INAF's opinion when deciding on sanctions. The MF is considering the recommendation to empower INAF to impose all sanctions, including those typified as "very serious", but stressed that the final decision on the authorization and revocation of banking licenses should remain in the hands of the government. In their view, it would be necessary to strike a balance between INAF's technical decisions and the approval of the government.

72. On CP 10, the authorities pointed out that Communication $\mathrm{n}^{\mathrm{o}} 163 / 05$ of INAF has provisions for the behaviour of staff and Board members of financial groups, including when carrying out their own operations. They also stated that banks have in place mechanisms to ensure that credits to insiders and related parties are not granted at preferential rates and those transactions to insiders, such as the credits to members of the bank's Board of Directors, require Board approval. However, upon, the IMF's recommendation, INAF will consider issuing a communication requiring explicitly that these credits be approved by the Board and stipulating they should not be granted at rates below other costumers.

73. On the recommendation that members of the Board of Directors of banks attend the annual tripartite meeting between INAF, external auditors, and bank senior staff, the Andorran authorities consider more useful to have separate meetings with Board members, without external auditors, to treat matters related to the management of the banking establishments.

74. On CP 16, INAF stressed that, with the recent increase of four staff members, it will be able to conduct on-site inspections with its own supervisory staff and recognized that an additional staff increase will be needed when it assumes the responsibility for insurance oversight. They also pointed out that external auditors provide an important support for supervision and that INAF is in constant communication with external auditors to clarify its requirements and ensure that they meet these requirements.

75. On CP 20, the authorities indicated that INAF's charter includes a provision regarding the transfer to INAF of the responsibility for supervising insurance companies and 
it commands the government to present to the General Council a new insurance regulation law. For the government, the new insurance regulation law is a priority and once this text will be approved, the responsibility for supervision of insurance will be carried out by INAF. The authorities also stressed their willingness to cooperate with foreign supervisors, as mandated in Andorra's current legal framework, a fact that, in their view, is not adequately reflected in the report. 